\title{
Piroxicam Percutaneous Permeation from Gels Through Membrane Models of Shed Snakeskin and Cellulose
}

\author{
Anis Y. Chaerunisaa ${ }^{1 *}$, Marline Abdassah ${ }^{1}$, Jutti Levita², Ellin Febrina ${ }^{2}$, Ulfiana Hafni ${ }^{3}$ \\ ${ }^{1}$ Departemen Farmasetika dan Teknologi Farmasi Fakultas Farmasi, Universitas Padjadjaran, Jatinangor, Indonesia \\ ${ }^{2}$ Departemen Farmakologi dan Farmasi Klinik Fakultas Farmasi, Universitas Padjadjaran, Jatinangor, Indonesia \\ ${ }^{3}$ Program Studi Sarjana Farmasi, Fakultas Farmasi, Universitas Padjadjaran, Jatinangor, Indonesia
}

Submitted 09 August 2020; Revised 27 January 2021; Accepted 10 February 2021; Published 21 June 2021

*Corresponding author: anis.yohana.chaerunisaa@unpad.ac.id

\begin{abstract}
Skin has a very important role in determining percutaneous absorption of active substance in topical administration. Study on percutaneous permeation of piroxicam from gel had been conducted using Franz Diffusion Cell with membrane model of shed snakeskin and cellulose. Piroxicam gels were made using Aqupec HV-505 base with 0; 2.5; 5; and 7.5\% of DMSO as an enhancer. The results showed that the most stable gel preparation was the one with 5\% DMSO (F2), so it was used for further investigation to which percutaneous permeation test. The permeation test was conducted in preparation without and with 5\% DMSO (F2) in vitro through shed snakeskin and cellulose membranes. The results showed that F2 increased the permeation rate by as much as $0.0281 \%$ per minute. In comparison, the permeation rate of formulation without DMSO (F0) was $0.012 \%$ per minute. It can be concluded that DMSO can increase piroxicam penetration through shed snakeskin. Permeation study using cellulose membrane on formula $\mathrm{F} 2$ revealed permeation rate as much as $0.006 \%$ per minute whereas that without DMSO (F0) was $0.0112 \%$ per minute.
\end{abstract}

Keywords: DMSO, cellulose membrane, percutaneous permeation, piroxicam, shed snakeskin.

\section{Permeasi Perkutan Piroksikam dari Sediaan Gel Melalui Model Membran Kulit Ular dan Selulosa}

\begin{abstract}
Abstrak
Kulit memiliki peran penting dalam menentukan absorpsi perkutan zat aktif pada rute pemberian obat secara topikal. Penelitian mengenai permeasi perkutan piroksikam dari sediaan gel telah dilakukan dengan menggunakan alat Franz Diffusion Cell dengan kulit ular dan selulosa sebagai model membran. Gel piroksikam dibuat dengan basis Aqupec HV-505 menggunakan dimetil sulfoksida (DMSO) sebagai enhancer dengan konsentrasi $0 ; 2,5 ; 5$; dan 7,5\%. Hasil penelitian menunjukkan bahwa sediaan gel dengan DMSO 5\% merupakan sediaan yang paling stabil sehingga sediaan ini digunakan untuk tahapan selanjutnya yaitu pengujian permeasi perkutan. Uji permeasi dilakukan terhadap sediaan tanpa DMSO (F0) dan dengan DMSO 5\% (F2) secara invitro melalui membran kulit ular dan membrane selulosa. Hasil pengujian menunjukkan bahwa formula F2 mengalami peningkatan laju permeasi piroksikam sebesar $0,0281 \%$ per menit. Sebagai perbandingan, laju permeasi dari sediaan tanpa DMSO (F0) adalah sebesar $0,012 \%$ per menit. Dari hal ini dapat diartikan bahwa DMSO terbukti dapat meningkatkan penetrasi piroksikam ke dalam kulit dengan model membran kulit ular. Uji permeasi melalui membran selulosa untuk sediaan dengan formula F2 menunjukkan nilai laju permeasi piroksikam sebesar $0,006 \%$ per menit sedangkan formula tanpa DMSO (F0) sebesar 0,0112\% per menit.
\end{abstract}

Kata Kunci: DMSO, membran kulit ular, membran selulosa, permeasi perkutan, piroksikam. 


\section{Pendahuluan}

Obat antiinflamasi nonsteroid (AINS) sering digunakan pada pengobatan osteoartritis dan rematoid artritis. Piroksikam merupakan salah satu obat anti-inflamasi nonsteroid dengan struktur oksikam. ${ }^{1,2}$ Pemberian oral piroksikam biasanya diikuti dengan adanya efek samping seperti kerusakan gastrointestinal, kerusakan hati, dan kerusakan fungsi ginjal. Untuk mengatasi masalah ini dapat digunakan OAINS topikal. Pemberian OAINS secara topikal memberikan keuntungan antara lain lebih mudah diterima pasien dan memberikan efek local pada jaringan yang dituju tanpa memberikan efek samping yang didapat jika diberikan secara oral..$^{3-5}$ Pemberian piroksikan secara topikal memberikan kadar obat aktif yang cukup tinggi pada sendi dan jaringan di bawah kulit tempat obat dioleskan, tanpa menimbulkan efek samping yang berarti. ${ }^{6-9}$ Meskipun pemberian piroksikan secara perkutan tidak sama efektivitasnya dengan pemberian secara oral, beberapa studi telah membuktikan bahwa piroksikam memiliki efektivitas ketika diberikan secara perkutan. ${ }^{6}$ Beberapa studi bahkan sudah mempelajari dan memprediksi absorpsi piroksikam secara perkutan dengan menggunakan beberapa macam peningkat penetrasi. ${ }^{10-15}$ Salah satu bentuk sediaan topikal yang telah banyak dipakai untuk sediaan dengan zat aktif yang memiliki aktivitas inflamasi dan anti rheumatik sehingga diharapkan membantu absoprsi perkutan adalah gel. ${ }^{16-19}$

Pada rute pemberian obat secara topikal, kulit merupakan bagian yang berperan penting karena menentukan absorpsi perkutan zat aktif. ${ }^{20}$ Pada umumnya absorpsi perkutan obat disebabkan oleh penetrasi langsung obat melalui stratum korneum. ${ }^{21}$ Stratum korneum sebagai jaringan keratin akan bertindak sebagai membran yang semipermeabel dan molekul obat berpenetrasi dengan cara difusi pasif. ${ }^{22,23}$ Faktor-faktor yang berperan dalam absorpsi perkutan obat adalah sifat obat itu sendiri, sifat pembawa, kondisi kulit dan adanya air. ${ }^{12,14}$

Berdasarkan sifat sawar kulit, maka dalam mengembangkan produk farmasi yang bertujuan untuk digunakan pada kulit dan menyediakan pengobatan untuk penghantaran ke kulit, sangat dianjurkan untuk melakukan pengujian secara in vitro untuk mempelajari penetrasi obat tersebut ke dalam kulit. ${ }^{10,14,20}$

Dalam pengujian permeasi perkutan secara in vitro, jumlah obat yang masuk dan berpenetrasi ke dalam kulit dihitung berdasarkan konsentrasi zat aktif yang terdapat di dalam cairan reseptor. Jumlah zat aktif ini merupakan zat aktif yang diabsorpsi oleh membran permeasi yang merupakan model dari stratum korneum pada jaringan kulit manusia. Berbagai jenis model membran permeasi telah digunakan pada pengujian permeasi in vitro. Kulit kadaver manusia dan kulit mamalia yang berbulu sedikit seperti tikus berbulu halus, tikus tidak berbulu, dan kulit babi sering digunakan pada pengujian in vitro. ${ }^{14}$ Membran yang digunakan pada penelitian ini adalah membran kulit ular dan membran selulosa nitrat. Membran kulit ular dipilih sebagai membran uji karena memiliki kesamaan struktur, komposisi, kandungan lipid, dan permeabilitas air dengan stratum korneum kulit manusia. Telah dilaporkan bahwa terdapat kesesuaian antara epidermis yang telah mengelupas dari dua spesies ular, yaitu Python morulus (Indian Phyton) dan Elaphe obsoleta (American black rat snake), sebagai model membran kulit manusia pada studi absorpsi. ${ }^{24}$ Telah melaporkan bahwa terdapat kemiripan antara kulit ular yang telah mengelupas dari Elaphe obsoleta dengan stratum korneum manusia dalam hal ketebalan, permeabilitas air, dan kandungan lipid. ${ }^{24}$ Selain itu, tingkat permeabilitas berbagai senyawa serta peran berbagai gugus fungsi membran kulit ular juga menyerupai membran kulit manusia. Keuntungan penggunaan membran kulit ular yang lainnya adalah tidak melukai dan tidak membunuh binatang karena didapat dari lepasan kulit pada siklus pelepasan normal dari ular. Selain itu membran kulit ular relatif mudah penanganannya. Sedangkan kelemahannya adalah perlu waktu yang cukup lama untuk mendapatkan membran kulit ular tersebut karena membran tersebut dilepaskan setiap dua sampai tiga bulan sekali. $^{24}$ Karena 
ketersediaan Elaphe obsoleta yang terbatas maka studi permeasi dilakukan dengan menggunakan kulit ular kobra spesies Naja naja khaotia sebagai model membran. Dari penelitian tersebut dilaporkan bahwa profil permeasi nikotin patches melalui kulit ular kobra dan epidermis manusia memiliki profil kinetik yang identik. Hal tersebut ditunjukkan oleh adanya hubungan yang linear antara jumlah kumulatif nikotin yang berpermeasi dengan $\mathrm{t}_{1 / 2}$. Bhasi, et al., menyatakan bahwa kulit ular Morelia virdis (Chondrophyton viridis) dan Acrantophds dunerill dapat digunakan untuk evaluasi efektivitas tabir surya. ${ }^{24,25}$ Selain membran kulit hewan, dapat digunakan pula membran buatan atau sintesis, misalnya membran selulosa nitrat, sebagai pengganti membran sel manusia. ${ }^{24,26}$

Penelitian ini bertujuan untuk mengetahui bagaimana permeasi perkutan piroksikam dari sediaan gel dengan basis Aqupec HV-505 menggunakan membran kulit ular sebagai model membran dan mengetahui sejauh mana perbedaan penetrasi perkutan melalui membran kulit ular dibandingkan dengan melalui membran selulosa.

Penelitian ini bertujuan untuk memberikan informasi mengenai permeasi perkutan sediaan gel piroksikam dengan basis Aqupec HV-505 dengan variasi konsentrasi enhancer DMSO melalui membran kulit ular dan membran selulosa.

\section{Metode}

\subsection{Alat}

Alat yang digunakan pada penelitian ini adalah, neraca analitik (Mettler Toledo, AL204), Franz Diffusion Cell, magnetic stirrer, oven (Memmert 200 dan Memmert 400-800), spatel, viskometer (Rion), dan $\mathrm{pH}$ meter (Mettler Toledo) serta alat gelas lain yang umum digunakan di Laboratorium Farmasetika Fakultas Farmasi Universitas Padjadjaran.

\subsection{Bahan}

Bahan-bahan yang digunakan untuk formulasi gel dan uji permeasi adalah Aqupec $H V-505 \AA$, trietanolamin, propilenglikol, dimetil sulfoksida (DMSO), natrium metabisulfit, nipagin, nipasol, dan air suling.

\subsection{Prosedur Rinci}

Penelitian dilakukan dengan tahapan sebagai berikut:

\subsubsection{Formulasi sediaan gel piroksikam} basis Aqupec $H V-505$ dengan variasi konsentrasi enhancer DMSO

Formula sediaan gel piroksikam menggunakan basis Aqupec $\mathrm{HV}$-505 dengan variasi konsentrasi enhancer DMSO dapat dilihat pada Tabel 1. Peningkat penetrasi atau enhancer DMSO digunakan karena merupakan salah satu enhancer yang efektif meningkatkan penetrasi perkutan sediaan transdermal. ${ }^{23}$

\subsubsection{Pembuatan gel piroksikam dengan} basis Aqupec $H V-505$

Aqupec HV-505 dikembangkan dalam sejumlah air panas pada mortir selama 24 jam dan diaduk homogen. Kemudian sedikit demi sedikit trietanolamin ditambahkan ke dalam basis dan diaduk sampai homogen. Piroksikam, metil paraben, dan propil paraben masing-masing dilarutkan dalam propilenglikol. Ketiganya kemudian dicampur dan selanjutnya ditambahkan basis gel sedikit demi sedikit sambil diaduk hingga homogen. DMSO ditambahkan sedikit demi sedikit sambil terus diaduk hingga didapatkan massa gel yang homogen.

\subsubsection{Evaluasi sediaan gel piroksikam}

Evakuasi fisik yang dilakukan terhadap gel piroksikam yang dibuat meliputi pengamatan organoleptis, konsistensi, perubahan $\mathrm{pH}$ serta perubahan viskositas selama penyimpanan.

\subsubsection{Penetapan kadar zat aktif piroksikam} dalam sediaan gel dengan Spektrofotometer UV

Penetapan kadar ini bertujuan untuk mengetahui stabilitas piroksikam dalam sediaan gel. Tahapan yang dikerjakan meliputi pembuatan larutan baku piroksikam, penentuan panjang gelombang serapan 
Tabel 1. Formula Sediaan Gel Piroksikam dengan Basis Aqupec HV-505

\begin{tabular}{lrrrr}
\hline \multirow{2}{*}{ Bahan } & \multicolumn{5}{c}{ Formula } \\
\cline { 2 - 6 } & F0 & F1 & F2 & F3 \\
\hline Aqupec HV-505 (\%) & 1,00 & 1,00 & 1,00 & 1,00 \\
Piroksikam (\%) & 0,50 & 0,50 & 0,50 & 0,50 \\
TEA (\%) & 3,00 & 3,00 & 3,00 & 3,00 \\
Propilenglikol (\%) & 20,00 & 20,00 & 20,00 & 20,00 \\
Metil Paraben (\%) & 0,20 & 0,20 & 0,20 & 0,20 \\
Propil Paraben (\%) & 0,05 & 0,05 & 0,05 & 0,05 \\
DMSO (\%) & - & $\mathbf{2 , 5 0}$ & $\mathbf{5 , 0 0}$ & $\mathbf{7 , 5 0}$ \\
Aquadest ad (mL) & 100,00 & 100,00 & 100,00 & 100,00 \\
\hline
\end{tabular}

Keterangan:

$\mathrm{F} 0=$ Formula gel piroksikam tanpa enhancer DMSO

$\mathrm{F} 1=$ Formula gel piroksikam dengan DMSO 2,5\%

$\mathrm{F} 2=$ Formula gel piroksikam dengan DMSO 5\%

maksimum dari piroksikam, pembuatan kurva baku piroksikam, preparasi sampel dari sediaan gel, serta penetapan kadar zat aktif piroksikam dalam sediaan gel.

\subsubsection{Uji Permeasi Perkutan}

Tahapan uji permeasi perkutan meliputi:

a. Penyiapan Bahan

1. Dapar fosfat $\mathrm{pH} 7,4$

2. Cairan Spangler, yaitu larutan yang digunakan untuk bacam membran selulosa sehingga membran tersebut memiliki sifat fisik dan komposisi yang mendekati stratum korneum. Komposisi cairan Spangler: ${ }^{27}$

$\begin{array}{lr}\text { Asam Palmitat } & 10 \mathrm{~g} \\ \text { Asam Oleat } & 15 \mathrm{~g} \\ \text { Asam Stearat } & 5 \mathrm{~g} \\ \text { Minyak Kelapa } & 15 \mathrm{~g} \\ \text { Skualen } & 5 \mathrm{~g} \\ \text { Parafin } & 10 \mathrm{~g} \\ \text { Kolesterol } & 5 \mathrm{~g} \\ \text { Lilin Putih } & 15 \mathrm{~g}\end{array}$

3. Semua bahan untuk cairan Spangler dicampurkan dan dilumerkan di atas penangas air pada suhu $80^{\circ} \mathrm{C}$ dan diaduk sampai homogen.

b. Penyiapan Membran

1. Membran kulit ular

Membran kulit ular yang digunakan dalam penelitian ini berasal dari lepasan kulit yang dilepaskan secara periodik setiap 3-4 bulan sekali dari tubuh ular piton spesies Chondropython viridis yang diperoleh dari Kebun Binatang Bandung. Kulit ular bagian dorsal dicuci dengan air suling dan direndam dengan air suling selama 24 jam. Membran diangkat dan dikeringkan pada suhu kamar dengan cara diletakkan di atas kertas saring untuk mempercepat pengeringan. Membran dipotong dengan diameter $2,5 \mathrm{~cm}$ dan membran siap digunakan.

\section{Membran selulosa}

Kertas Whatman no. 1 direndam dalam cairan Spangler selama 15 menit. Membran diangkat dan dikeringkan pada suhu kamar dengan cara diletakkan di atas kertas saring untuk mempercepat pengeringan. Membran dipotong dengan diameter $2,5 \mathrm{~cm}$ dan membran siap digunakan.

\section{c. Uji Permeasi perkutan Sediaan Gel Piroksikam}

Uji permeasi perkutan dilakukan dengan menggunakan alat Franz Diffusion Cell. ${ }^{28}$ Pada pengujian ini rangkaian alat yang dipakai terdiri dari sel permeasi perkutan, pompa peristaltik, pengaduk, beaker glass, penangas air, penampung reseptor, termometer dan selang silikon dengan diameter $4 \mathrm{~mm}$. Formula sediaan uji ditimbang $1 \mathrm{~g}$ dan diratakan di atas membran. Suhu sistem dijaga $37 \pm 0,5^{\circ} \mathrm{C}$ dengan cairan reseptor 
$100 \mathrm{~mL}$. Cairan reseptor ini berisi dapar fosfat $\mathrm{pH} 7,4$. Pompa peristaltik menghisap cairan reseptor dari beaker glass kemudian dipompa ke sel permeasi perkutan sehingga terjadi aliran secara hidrodinamis. Kemudian cairan dialirkan lagi ke reseptor. Proses dilakukan selama 5 jam. Setiap selang waktu 30 menit dilakukan pengambilan sampel dari cairan reseptor sebanyak $5 \mathrm{~mL}$ dan setiap pengambilan selalu diganti dengan dapar fosfat $\mathrm{pH} 7,4$ sebanyak $5 \mathrm{~mL}$. Konsentrasi piroksikam yang terdifusi diukur dengan spektrofotometer ultra violet pada panjang gelombang $354 \mathrm{~nm}$.

\subsubsection{Uji Keamanan}

Pengujian keamanan sediaan gel piroksikam dengan berbagai variasi konsentrasi enhancer DMSO dilakukan terhadap 10 orang sukarelawan untuk memenuhi syarat analisis statistik. Tehnik yang digunakan adalah uji oles pada kulit tangan (Patch test). Pelaksanaan uji keamanan telah mendapatkan ijin etik dari Komisi Etik Fakultas Kedokteran Universitas Padjadajaran.

\section{Hasil}

3.1. Evaluasi Fisik Sediaan Gel Piroksikam dengan Variasi Konsentrasi Enhancer

\subsubsection{Pengamatan organoleptis}

Pengamatan organoleptis terdiri dari pengamatan terhadap warna, bau, tekstur, dan konsistensi. Pemeriksaan organoleptis ini dilakukan pada semua formula. Hasil pengamatan menunjukkan bahwa semua formula memiliki warna kuning bening, tidak berbau, tekstur yang halus, dan tidak terjadi perubahan konsistensi.

\subsubsection{Pengamatan $\mathrm{pH}$ sediaan gel dengan} variasi konsentrasi enhancer

Berdasarkan British Pharmacopoeia $2016^{29}$, pH gel piroksikam adalah 6-8. Pengukuran $\mathrm{pH}$ dilakukan dengan mengencerkan sediaan gel dengan aquadest kemudian diukur pada $\mathrm{pH}$ meter Mettler Toledo. Hasil pengukuran memperlihatkan bahwa semua formula memenuhi persyaratan $\mathrm{pH}$ ideal gel piroksikam yaitu $<8$. Hasil ratarata pengukuran $\mathrm{pH}$ masing-masing formula gel piroksikam diperlihatkan pada Gambar 1.

\subsubsection{Pengamatan viskositas}

Viskositas atau kekentalan gel diukur dengan Viskometer Brookfield. Hasil ratarata pengukuran viskositas dapat dilihat pada Gambar 2. Dari Gambar 2 dapat dilihat bahwa formula gel piroksikam tanpa enhancer DMSO memiliki nilai viskositas yang lebih tinggi dibandingkan dengan formula gel yang mengandung DMSO.

\subsection{Penentuan Kadar Piroksikam dalam Sediaan Gel Selama Penyimpanan \\ Grafik kadar piroksikam dalam sediaan} diperlihatkan pada Gambar 3. Hasil penelitian memperlihatkan bahwa selama penyimpanan, kadar piroksikam dalam sediaan gel pada semua formula mengalami peningkatan. Peningkatan paling tinggi diperlihatkan oleh F3 dimana pada pengukuran hari ke-0

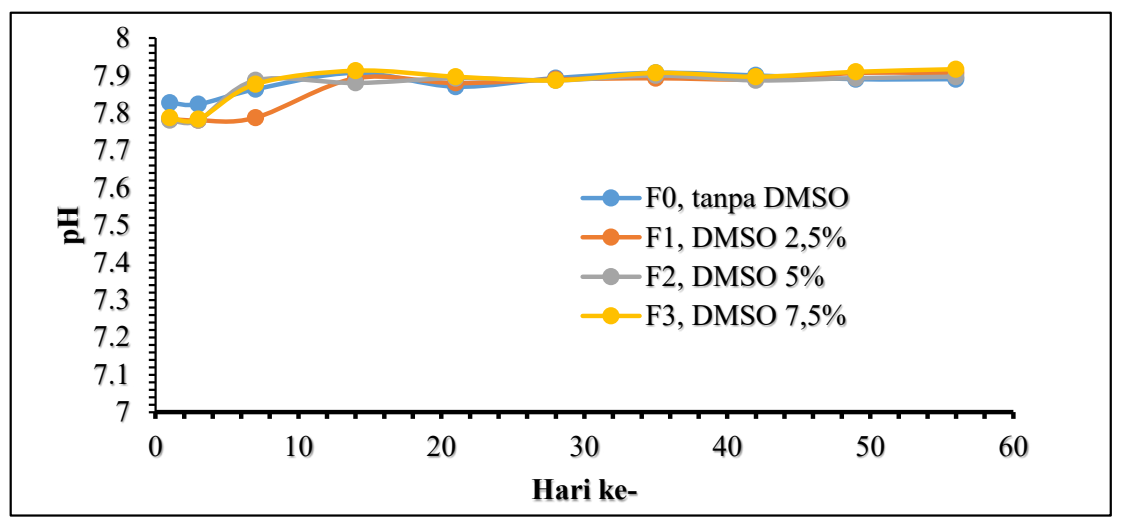

Gambar 1. Grafik Hasil Rata-rata pH gel Piroksikam dengan Enhancer DMSO Selama Waktu Penyimpanan 


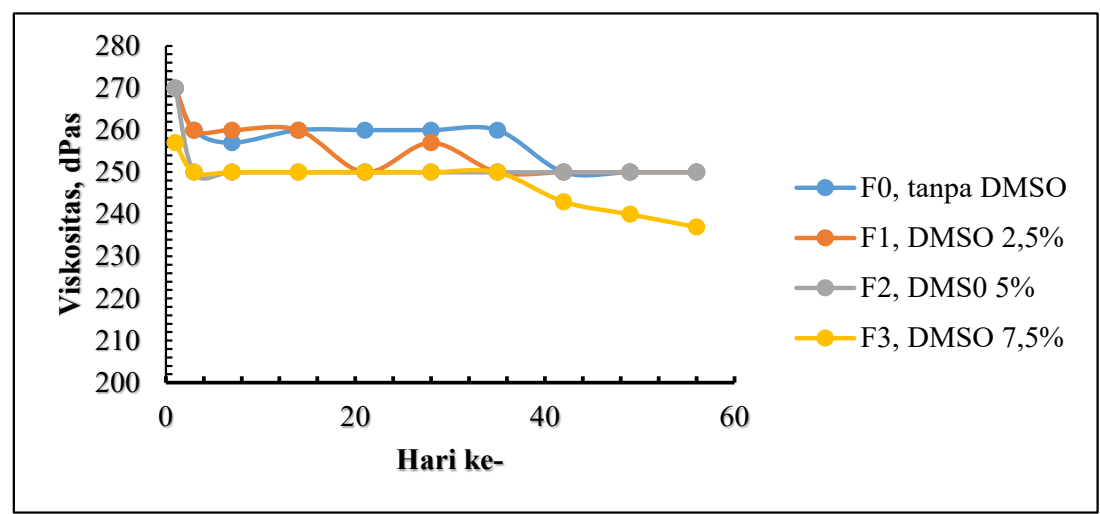

Gambar 2. Grafik Hasil Rata-rata Viskositas Gel Piroksikam dengan Enhancer DMSO Selama Waktu Penyimpanan

konsentrasi zat aktif piroksikam sebesar $93 \%$ sedangkan setelah penyimpanan 56 hari, konsentrasi piroksikam yang terukur dalam gel meningkat menjadi $102 \%$.

\subsection{Pengujian Permeasi Piroksikam}

Setelah dilakukan evaluasi fisik dan stabilitas terhadap sediaan gel piroksikam maka F2 ditetapkan sebagai formula yang memenuhi kriteria sebagai formula yang paling stabil, karena memiliki viskositas yang paling selama penyimpanan dan memperlihatkan peningkatan konsentrasi yang paling kecil selama penyimpanan, dibandingkan dengan formula lain. Terhadap formula F2 ini kemudian dilakukan uji permeasi perkutan melalui membran kulit ular dan membran selulosa. Pengujian permeasi perkutan juga dilakukan terhadap formula gel tanpa DMSO, sebagai formula blanko. Hasil pengukuran laju permeasi piroksikam melalui membran kulit ular terlihat pada Gambar 4.
Profil permeasi perkutan piroksikam dari sediaan gel melalui membran selulosa dapat dilihat pada Gambar 5.

\section{Pembahasan}

Dari Gambar 1 dapat dilihat bahwa $\mathrm{pH}$ semua formula gel piroksikam hampir sama yaitu 7,78-7,92 dan setelah 56 hari penyimpanan semua formula gel piroksikam secara statistika menunjukkan perubahan $\mathrm{pH}$ tetapi masih dalam rentang yang sesuai dengan British Pharmacopoeia 2016. ${ }^{29}$ Penambahan DMSO ke dalam formula gel piroksikam tidak terlalu mempengaruhi nilai $\mathrm{pH}$ sediaan. Hal ini disebabkan karena sifat DMSO yang bersifat amfoter, yaitu asam lemah dan basa lemah. Ditinjau dari perubahan $\mathrm{pH}$ sediaan, formula yang paling konstan adalah pada sediaan gel dengan DMSO 5\% (F2). Oleh karena itu F2 dapat dianggap sebagai formula yang paling baik dibandingkan dengan F1 dan F3.

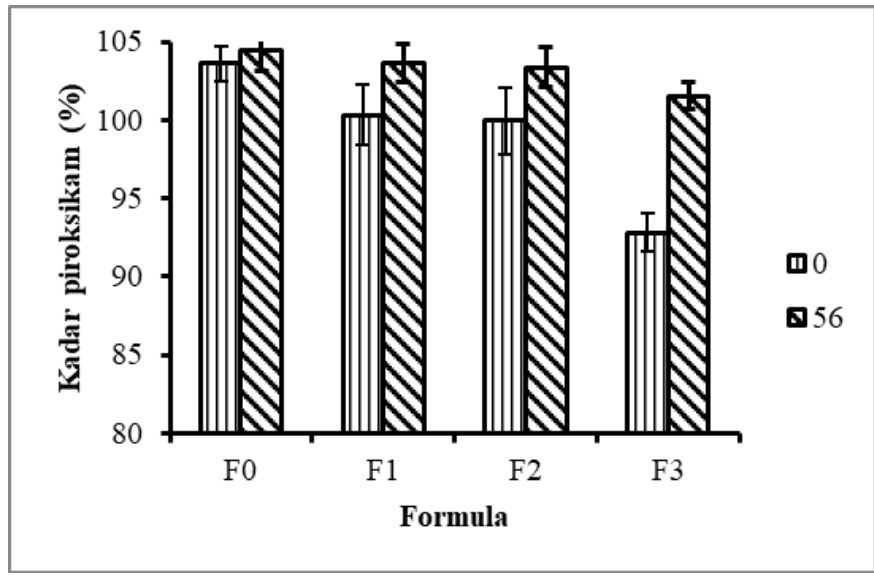

Gambar 3. Grafik Kadar Piroksikam dalam Sediaan Gel 


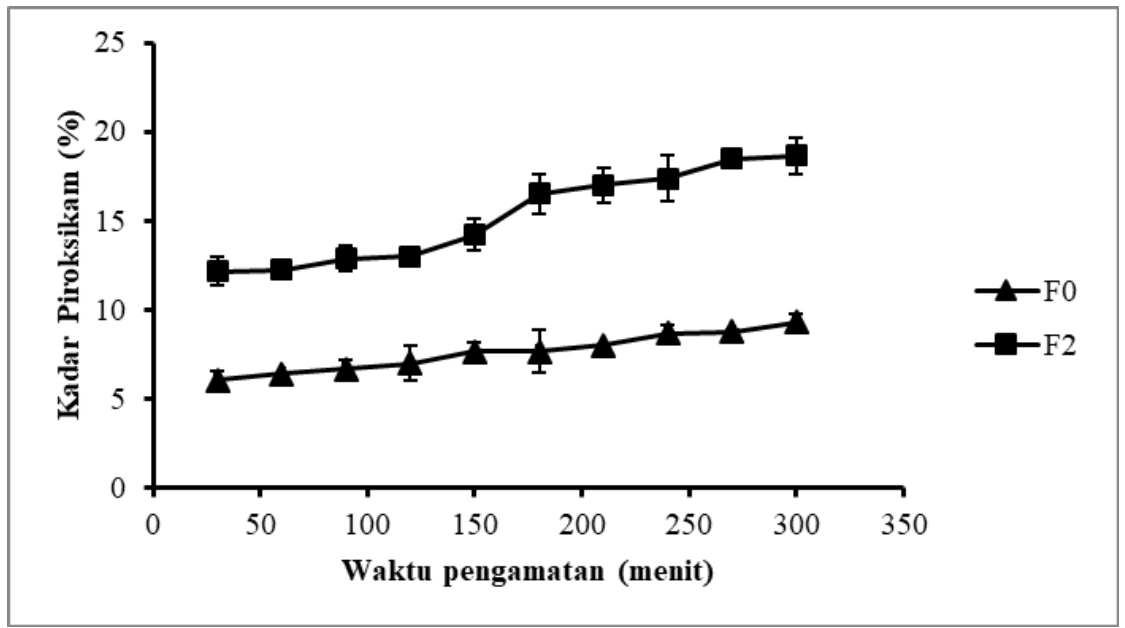

Keterangan:

F0 $=$ Formula gel Piroksikam tanpa enhancer DMSO

F2 = Formula gel Piroksikam dengan DMSO 5\%

Gambar 4. Grafik Profil Permeasi Perkutan Piroksikam dalam Sediaan Gel Melalui Membran Kulit Ular

Hasil analisis statistika dengan Anava menggunakan desain acak sempurna terhadap $\mathrm{pH}$ dengan derajat kepercayaan 95\% menunjukkan bahwa Ho ditolak karena $\mathrm{F}_{\text {hitung }}$ lebih besar daripada $\mathrm{F}_{\text {tabel }}$. Hal ini berarti bahwa terdapat perbedaan harga $\mathrm{pH}$ gel terhadap lama penyimpanan pada masingmasing formula.

Pengamatan selama 56 hari terhadap gel piroksikam yang dibuat menunjukkan bahwa semua formula gel mengalami penurunan viskositas yang tidak signifikan. Penurunan viskositas tersebut dapat disebabkan oleh interaksi DMSO dengan matriks gel. Dari Gambar 2 terlihat bahwa perubahan viskositas yang paling konstan terjadi pada formula gel piroksikam dengan enhancer DMSO 5\% (F2). Hasil analisis statistika desain acak sempurna terhadap harga viskositas dengan derajat kepercayaan 95\% memperlihatkan bahwa Ho ditolak karena $\mathrm{F}_{\text {hitung }}$ lebih besar dibandingkan dengan $\mathrm{F}_{\text {tabel }}$. Hal ini berarti bahwa terdapat perbedaan mengenai harga viskositas gel terhadap lama penyimpanan pada masingmasing formula. Kekentalan atau viskosotas dari sediaan gel mengalami perubahan selama penyimpanan, yang disebabkan menguapkan air sebagai komponen penyusun gel.

Untuk mengetahui stabilitas sediaan selama penyimpanan dilakukan pengamatan terhadap kadar piroksikam dalam sediaan yang diukur dengan spektrofotometer UV.
Pada British Pharmacopoeia 2016 disebutkan bahwa persyaratan kandungan piroksikam dalam sediaan gel adalah antara 95-105\%. ${ }^{29,30}$ Berdasarkan hasil pengukuran dengan spektrofotometer, kadar piroksikam dalam sediaan gel pada semua formula mengalami peningkatan, tetapi peningkatan kadar tersebut masih memenuhi persyaratan yang disebutkan pada British Pharmacopoeia tahun 2016. ${ }^{29}$ Peningkatan kadar ini disebabkan karena adanya penguapan dari air sebagai penyusun basis gel, yang menyebabkan terjadinya efek pengentalan pada konsentrasi piroksikam sebagai zat aktif. Hasil ini juga dapat dijelaskan dari hasil pengukuran viskositas sediaan dimana selama peningkatan memperlihatkan peningkatan kekentalan. Dapat disimpulkan bahwa sediaan F0, F1, dan F2 stabil selama penyimpanan, sedangkan untuk F3 terjadi peningkatan kadar.

Dari Gambar 4 terlihat bahwa formula gel F2 dengan DMSO 5\% memiliki laju permeasi $\mathrm{dc} / \mathrm{dt}=0.0281 \%$ per menit sedangkan laju permeasi formula gel piroksikam tanpa DMSO dc/dt $=0.012 \%$ per menit. Laju permeasi formula dengan DMSO 5\% lebih tinggi dibandingkan dengan formula tanpa DMSO. Hal ini menunjukkan bahwa penetrasi piroksikam dari sediaan gel F2 lebih baik dibandingkan dengan formula blangko tanpa DMSO. Hal ini dapat diartikan 


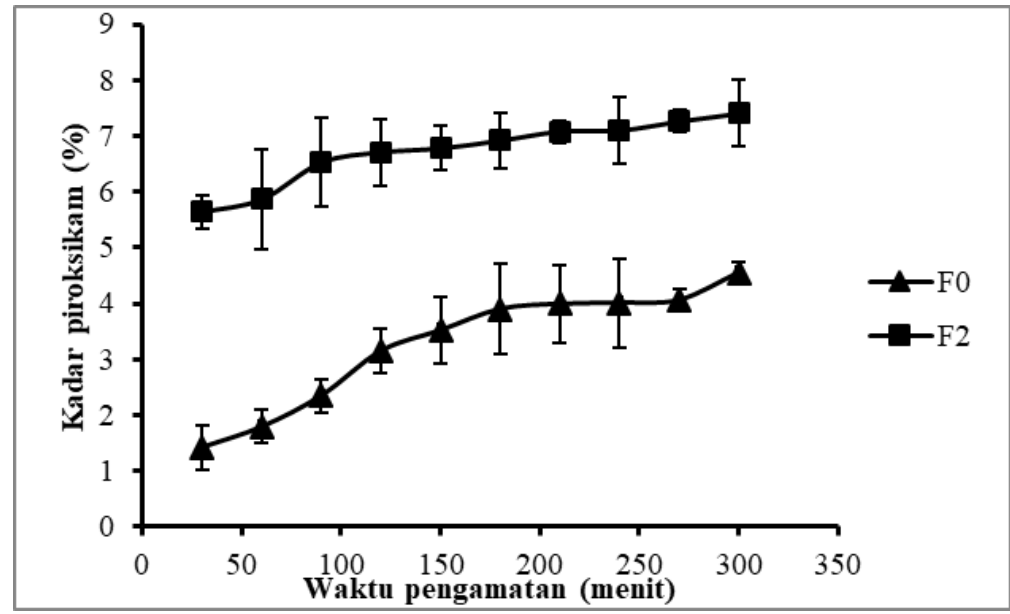

Keterangan:

F0 $=$ Formula gel Piroksikam tanpa enhancer DMSO

F2 = Formula gel Piroksikam dengan DMSO 5\%

Gambar 5. Grafik Profil Permeasi Perkutan Piroksikam dalam Sediaan Gel Melalui Membran Selulosa

bahwa DMSO terbukti dapat meningkatkan penetrasi piroksikam ke dalam membran kulit ular.

Dari Gambar 5 terlihat bahwa formula gel dengan DMSO 5\% (F2) memiliki laju permeasi $\mathrm{dc} / \mathrm{dt}=0.006 \%$ per menit sedangkan formula gel piroksikam tanpa DMSO (F0) memiliki laju permeasi $\mathrm{dc} / \mathrm{dt}=0.0112 \%$ per menit. Laju permeasi formula gel dengan DMSO 5\% lebih rendah dibandingkan dengan formula tanpa DMSO. Secara teoritis penambahan DMSO sebagai enhancer pada formula gel seharusnya dapat meningkatkan penetrasi zat aktif. Dari Gambar 5 terlihat bahwa formula dengan DMSO 5\% pada menit pertama dapat melepaskan zat aktif yang lebih tinggi daripada formula tanpa DMSO. Akan tetapi pada menit-menit berikutnya penetrasi zat aktif dari sediaan gel sangat sedikit. Hal ini berarti bahwa membran selulosa kurang sesuai untuk digunakan dalam uji permeasi yang menggunakan DMSO sebagai enhancer. Hasil yang didapat membuktikan bahwa penggunaan lepasan kulit ular sebagai membran permeasi memberikan hasil yang lebih baik yang disebabkan karena susunan kimia dari membran ular lebih mirip dengan susunan kimia stratum korneum pada kulit manusia sehingga proses permeasi lebih mendekati keadaan yang sebenarnya pada kulit.
Membran selulosa yang telah dibacam dengan cairan Spangler bersifat lipofilik sama halnya dengan piroksikam. Kemungkinan yang terjadi adalah ketika piroksikam terabsorpsi ke dalam membran selulosa, maka piroksikam terperangkap pada membran selulosa tersebut, karena sifatnya yang samasama lipofilik. Piroksikam yang terjerat dalam membran selulosa tersebut tidak dapat berpenetrasi lebih lanjut ke lapisan stratum korneum, sehingga jumlah piroksikam yang terpenetrasi melalui membran selulosa pada menit-menit selanjutnya tidak terlalu banyak. ${ }^{24}$

Pengujian keamanan sediaan gel piroksikam dilakukan terhadap 10 orang sukarelawan dan memberikan hasil bahwa formula gel tanpa dan dengan DMSO tidak menyebabkan iritasi, berupa kemerahan atau pembengkakan pada punggung tangan 10 sukarelawan. Dari hasil uji keamanan tersebut dapat disimpulkan bahwa semua formula gel piroksikam yang dibuat aman untuk digunakan.

\section{Simpulan}

Sediaan gel piroksikam basis Aqupec $H V-505$ yang mengandung variasi konsentrasi enhancer DMSO mempunyai kestabilan fisik organoleptik dan konsistensi yang baik selama 56 hari penyimpanan. $\mathrm{pH}$ sediaan 
gel basis Aqupec HV-505 yang mengandung variasi konsentrasi enhancer DMSO selama 56 hari penyimpanan masih memenuhi persyaratan seperti yang disebutkan pada British Pharmacopeia yaitu 6-8.

Laju permeasi formula gel piroksikam dengan DMSO 5\% (F2) melalui membran kulit ular lebih tinggi $(0.0281 \%$ per menit) dibandingkan dengan formula tanpa DMSO (F0) $\quad(0.012 \%$ per menit). Untuk membran selulosa, laju permeasi formula gel piroksikam dengan DMSO 5\% (F2) lebih rendah $(0.006 \%$ per menit) dibandingkan dengan formula tanpa DMSO (F0) (0.0112\% per menit). Laju permeasi piroksikam melalui membran kulit ular lebih baik daripada melalui membran selulosa.

Semua formula gel piroksikam yang dibuat aman digunakan karena tidak menimbulkan iritasi pada punggung tangan sukarelawan dengan kriteria sehat, dewasa berumur 25-35 tahun dengan jenis kelamin pria dan wanita.

\section{Daftar Pustaka}

1. Dignesh M, Ashish D, Dinesh R. Formulation design \& development of piroxicam emulgel. Int. J. Pharm. Tec. Res., 2012, 4 (3), 1332-1344.

2. Curdy C, Kalia YN, Naik A, Guy RH. Piroxicam delivery into human stratum corneum in vivo: iontophoresis versus passive diffusion. Journal of controlled release. 2001 Sep 11;76(1-2):73-9.

3. Aliberti AL, de Queiroz AC, Praça FS, Eloy JO, Bentley MV, Medina WS. Ketoprofen microemulsion for improved skin delivery and in vivo anti-inflammatory effect. AAPS PharmSciTech. 2017 Oct;18(7):2783-91, DOI: 10.1208/s12249-017-0749-6.

4. Nakamura A, Mori D, Tojo K. Evaluation of the predicted time-concentration profile of serum tulobuterol in human after transdermal application. Chemical and Pharmaceutical Bulletin. 2012 Mar 1;60(3):300-5.

5. Hatanaka T, Yoshida S, Kadhum WR, Todo $\mathrm{H}$, Sugibayashi K. In silico estimation of skin concentration following the dermal exposure to chemicals. Pharmaceutical research. 2015 Dec;32(12):3965-74.

6. Chakraborty, A., Devi, RKB. Rita, S. Sharatchandra, Kh. Singh, Th. I. Preliminary studies on anti-inflammatory and analgesic activities of Spilanthes acmella in experimental animal models. Indian Journal Pharmacology, 2014, 36 (3): 148-150.

7. Oshizaka T, Kikuchi K, Kadhum WR, Todo H, Hatanaka T, Wierzba K, et al. Estimation of skin concentrations of topically applied lidocaine at each depth profile. International journal of pharmaceutics. 2014 Nov 20;475(12):292-7.

8. Polak S, Ghobadi C, Mishra H, Ahamadi M, Patel N, Jamei M, et al. Prediction of concentration-time profile and its inter-individual variability following the dermal drug absorption. Journal of pharmaceutical sciences. 2012 Jul 1;101(7):2584-95

9. Jung EC, Maibach HI. Animal models for percutaneous absorption. Topical drug bioavailability, bioequivalence, and Penetration. 2014:21-40.

10. Shin SC, Cho CW, Oh IJ. Enhanced efficacy by percutaneous absorption of piroxicam from the poloxamer gel in rats. International journal of pharmaceutics. 2000 Jan 5;193(2):213-8.

11. Derry S, Conaghan P, Da Silva JA, Wiffen PJ, Moore RA. Topical NSAIDs for chronic musculoskeletal pain in adults. Cochrane Database of Systematic Reviews. 2016(4)

12. Horita D, Hatta I, Yoshimoto M, Kitao Y, Todo H, Sugibayashi K. Molecular mechanisms of action of different concentrations of ethanol in water on ordered structures of intercellular lipids and soft keratin in the stratum corneum. Biochimica et Biophysica Acta (BBA)-Biomembranes. 2015 May 1;1848(5):1196-202.

13. Dancik Y, Anissimov YG, Jepps OG, Roberts MS. Convective transport of highly plasma protein bound drugs 
facilitates direct penetration into deep tissues after topical application. British journal of clinical pharmacology. 2012 Apr;73(4):564-78.

14. Abd E, Yousef SA, Pastore MN, Telaprolu $\mathrm{K}$, Mohammed $\mathrm{YH}$, Namjoshi S, et al. Skin models for the testing of transdermal drugs. Clinical pharmacology: advances and applications. 2016;8:163.

15. Oesch F, Fabian E, Guth K, Landsiedel R. Xenobiotic-metabolizing enzymes in the skin of rat, mouse, pig, guinea pig, man, and in human skin models. Archives of Toxicology. 2014 Dec 1;88(12):2135-90.

16. Uzor PF, Mbah CJ, Omeje EO. Perspectives on Transdermal Drug Delivery. Journal of Chemical and Pharmaceutical Research. 2011, 3(3): 680-700.

17. Ashley NT, Weil ZM, Nelson RJ. Inflammation: mechanisms, costs, and natural variation. Annual Review of Ecology, Evolution, and Systematics. 2012 Dec 1;43:385-406.

18. Harirforoosh S, Asghar W, Jamali F. Adverse effects of nonsteroidal antiinflammatory drugs: an update of gastrointestinal, cardiovascular and renal complications. Journal of Pharmacy \& Pharmaceutical Sciences. 2013;16(5):821-47.

19. Zeng C, Wei J, Persson MS, Sarmanova A, Doherty M, Xie D, et al. Relative efficacy and safety of topical non-steroidal antiinflammatory drugs for osteoarthritis: a systematic review and network metaanalysis of randomised controlled trials and observational studies. British journal of sports medicine. 2018 May 1;52(10):642-50.

20. Tippavajhala VK, de Oliveira Mendes $\mathrm{T}$, Martin AA. In vivo human skin penetration study of sunscreens by confocal Raman spectroscopy. AAPS PharmSciTech. 2018 Feb;19(2):753-60. DOI: $10.1208 / \mathrm{s} 12249-017-0852-8$

21. Zhang J, Sun M, Fan A, Wang Z, Zhao Y. The effect of solute-membrane interaction on solute permeation under supersaturated conditions. International journal of pharmaceutics. 2013 Jan 30;441(1-2):389-94.

22. Panzade PS, Puranik P. Iontophoresis: A Functional Approach for Enhancement of Transdermal Drug Delivery Asian Journal of Biomedical and Pharmaceutical Sciences 2(11) 2012, 01-08.

23. Jung E, Kang YP, Yoon IS, Kim JS, Kwon SW, Chung SJ, et al. Effect of permeation enhancers on transdermal delivery of fluoxetine: in vitro and in vivo evaluation. International journal of pharmaceutics. 2013 Nov 18;456(2):362-9.

24. Itoh T, Xia J, Magavi R, Nishihata T, Rytting JH. Use of shed snakeskin as a model membrane for in vitro percutaneous penetration studies: comparison with human skin. Pharmaceutical research. 1990 Oct;7(10):1042-7.

25. Bhasi K, Riga AT, Alexander KS. Characterization of snakeskin by thermoanalytical techniques. Journal of thermal analysis and calorimetry. 2004 Jan;75(1):269-76.

26. Lee KE, Choi YJ, Oh BR, Chun IK, Gwak HS. Formulation and in vitro/in vivo evaluation of levodopa transdermal delivery systems. International journal of pharmaceutics. 2013 Nov 18;456(2):4326.

27. Agoes G. Penelitian Difusi Asam Salisilat dan Kloramfenikol dari Sediaan Semisoloda dengan Pembawa Vaselin, Campuran Vaselin Propilenglikol dan Vaselin Lemak Bulu Domba secara In vitro. Acta Pharmaceutica IX (3). 1986.

28. Ujwala A, Shinde UA, Modani SH, Singh KH. Design and Development of Repaglinide Microemulsion Gel for Transdermal Delivery. AAPS PharmSciTech, 2018, Vol. 19(1), January 2018.

29. British Pharmacopoiea Comissi on, British Pharmacopoiea 2016, London, TSO, 2016

30. Khullar R, Kumar D, Seth N, Saini S. Formulation and evaluation of mefenamic acid emulgel for topical delivery. Saudi pharmaceutical journal. 2012 Jan 1;20(1):63-7. 